\title{
Promoting Religious Dimension in Conflict Resolution: A Review on Mohammed Abu-Nimer Thoughts
}

\author{
Muhammad Saifullah Rohman \\ Research Center for Society and Culture \\ e-mail: saifullah.rohman0I@gmail.com
}

\begin{abstract}
The aim of this paper is to review Mohammed Abu Nimer thoughts on the field of conflict resolution, peace-building and inter-religious dialogues. As a thinker and practitioner of conflict resolution, he built his work based on his intimate relationship with conflicts. To review his thoughts, this paper traced and observed his main ideas about conflict resolution based on his writings; books, journals, articles, etc. Thus, the findings show that Mohammed Abu Nimer draws upon his thoughts by referring to his religion, Islam. Therefore, Islam as a religion supports peace-building of civilization through its teaching to Muslims. Although Islam became the basis of his works on conflict resolution, it does not mean that he insists it to be used in conflict resolution. His idea is promoting religious dimension in conflict resolution which makes religion as a source of peace rather than a source of conflict. Then, he proves the limit on peace-building and inter-religious dialogue as a means to reach peace between two sides of a conflict. Therefore, peace-building activists should acknowledge and accommodate any possible ways to mediate the conflicting parties in order to make peace.
\end{abstract}

\section{Keywords:}

Religious Dimension, Conflict Resolution, Peace-building, Dialogue

\section{Introduction}

Conflict is a part of our life and a natural consequence of the diversity, but the important thing to do is how to maintain it and not escalate it to violence. Arskal Salim argues that conflict is a consequence of 
diverse experiences and various lives (Salim 2000:359). As a consequence in this life, people must deal and negotiate with the diversity in this universe. Therefore, conflicts as parts of people's lives must be treated properly and not transformed it into violence. There are some efforts to solve conflicts and one of the most discussed ideas is dialogue. Dialogue is assumed as ineffective way to reconcile, to get mutual understanding, to achieve agreement from the two sides. Somehow, dialogue is not easy to be implemented due to some of the difficulties within. As Mohammed Abu-Nimer said that dialogue is a dangerous business since we bring two conflicting groups on the same table (Nimer 2002). Although it is difficult to be implemented, dialogue has certain benefits to build a bridge of understanding and eliminate hatred. Try to understand other people's ideas, stories, reasons, and they will develop mutual respect. That is why dialogue as a bridge to connect both sides of conflicting groups must be built as the first step to deescalate the conflict. In other sense, dialogue is an effective way to eliminate hatred where two opponent groups will hear each other perspective and get the essence of stories.

Since dialogues have positive sides on building understanding, many agreements of negotiations to overcome conflicts have been conducted. However, negotiations and dialogues often neglected religious dimension both in formal and informal negotiation processes. Thus, religions are often manipulated and assumed as the source of conflicts and chaotic situations rather than to explore them as the source of peace. In explaining that situation, Cherian George (2016) expresses that major episodes of religious offense and the feeling of being offended are not a natural and spontaneous product of human diversity, but rather performances orchestrated by political entrepreneurs in their quest of power (George 2016:1). The quest of power is the source of problems in this world where people often put so much effort to manipulate and orchestrate religions for their interest.

DINIKA, Volume 3, Number I, January - April 2018 
The works of Mohammed Abu-Nimer show that he tried to dig and cultivate religious dimension to be implemented in the process of dialogue. He believes that religious dimension will broadly engage members of religions to develop their understanding of religion to overcome problems, not to escalate problems or conflicts. For instance, Mohammed AbuNimer states that religious dimension in the Israeli-Palestinian conflict has always been politically manipulated and exploited by all sides and parties in order to mobilize mass support for certain political outcomes (Nimer 2004:495). Meanwhile, according to Cherian George, many observers describe these conflicts as primordial, rooted in tribal psychology and reinforced messages of prophets and preachers. His work begins with the intuition that conflicts occurred as the result of sophisticated campaigns manufactured by political entrepreneurs working to further their own strategic interest (George 2016:xiv). Then, we must be aware to see any interest in certain case of conflicts which is not merely religion base but rather a political agenda which utilizes religion as a means to gain political entrepreneurs interest. This paper does not attempt to seek the source of conflicts but how to solve conflicts by proposing religious dimension through dialogue and peace-building which is developed by Mohammed Abu-Nimer.

Interestingly, Mohammed Abu-Nimer ideas on interfaith dialogue will not separate us with our religion, but it will increase our spirituality and understand others with the new paradigm. If we look at the identity of Hamas, Laskar Jihad, and Zionist movement at the conflict of IsraeliPalestinian, these different religious identities will be recognized as the source of cooperation to live together as diverse Abrahamic religions, rather than contestation over the holy land within their religious history. When cooperation to live together in harmony is more preferred, mutual understanding among different religious identities is accepted. Political entrepreneurs then will fail to fabricate religious issues in order to create a conflict and escalate it into violence. 
Meanwhile, conflicts are often portrayed as the result of contestation among different religions, cultures, identities and others. As a source of conflicts, religions are often easily triggered and ask their adherents to involve in it. There are many instances of conflicts regarding religions occurring all over the world, especially in the Middle East as well as in Indonesia. The history of crusade war between Muslims and Christians shapes and re-frames the conflicts among them in this new era. In other story, the conflicts in Poso and Ambon in Indonesia are also assumed as the conflict between Muslims and Christian in the name of religion. Therefore, some proponent of anti-religions assumed that religions are justified as the source of conflict. Then, religions should not have been included in the process of reconciliation since it will escalate the tension.

Whether it is true or not that religions became the source of conflicts, some proponents of religions have different ideas. They still believe and tried to find, build and develop certain elements of religions to be implemented in peace-building and non-violence agenda. Mohammed Abu-Nimer as one of these proponents has a strong commitment to promote the non-violent peace-building through interfaith dialogue. The basis of his ideas is the universal humanity that unites human all over the world no matter their identity, religion, and culture. But at the same time, they also belong to a particular religion that they believe in. The particular differences of religions in interfaith dialogue is meant to understand their religious teaching to emphasize the mutual understanding of others and create tolerance (Khamami 2014:256). Therefore, this article is trying to explore the thought of Mohammed Abu-Nimer on the interfaith dialogue as one of the sources of peace-building. Then, he developed particular religious dimensions in the interfaith dialogue and its limitation. Since the essence of the ideas of Abu-Nimer is to shift the paradigm of religion's role in peace-building process which is often neglected in most researches and practices.

DINIKA, Volume 3, Number I, January - April 2018 


\section{Abu-Nimer's Thought on Interfaith Dialogue}

Stuart J. Kaufman (2006) on his article defines the failure of conventional peace making. At the level of ethnic conflicts, he asserts that the conventional wisdom on ethnic wars was pessimistic. In the conventional peace making, the intervention of third party has a significant role if they success to enforce the bargain (Kaufmann 2006:202). At least, the success of peace-making in ethnic wars or conflicts will stay for a few years, but other conflicts will reappear. In sum, the conventional peacemaking with the intervention of third party only represses the conflicting parties to obey the agreement, but to what extent will they obey it? And for this conventional peace-making, the use of military power often creates another problem of violent actions. The third party in conflict resolution is primarily needed, but with notion on its role as a medium to bridge both sides with mutual understanding. If the role of third party in conflict resolution by implementing military power or political power, it is most likely to escalate the conflict tension.

Mohammed Abu-Nimer was disturbed with such conditions where the role of third-party only for the sake of intervention. He then proposed the role of third party as the mediator on the conflict and not to interfere. Most of his ideas were developed from the non-violence approach in peace-building with interfaith dialogue. Mohammed Abu-Nimer gave explanation to anyone who criticized the interfaith dialogue. As one model of dialogue, interfaith dialogue is often assumed as an alternative to replace the debate model. In a dialogue, participants are expected to understand others' views, build tolerance, and respect others religions. Meanwhile, debates tend to seek the weakness of others' religions and not accept the others' differences (Kaufmann 2006:257).

Interfaith dialogue was often misunderstood as the arena of religious conversion since each participant shares their own understanding of their religion toward certain issues. In fact, interfaith dialogues are meant to hold 
one's faith while simultaneously try to understand another person's faith (Shafiq 2007:2). Therefore, some of scholars and religious leaders criticize this interfaith model as the basis to understand others. So, Mohammed Abu-Nimer argues to explain his understanding on interfaith model which concerns on the conversion issue. Basically, the importance of interfaith dialogue according to Mohammed Abu-Nimer is to develop and get deep understanding on their own religion or faith and recognize and accept others' religions (Khamami 2014:257). It needs the honesty from each participant to share their religious teaching properly and clearly, and at the same time the openness to hear others. So, in the interfaith dialogue there is no rigid models to be implemented and it is more contextualized according to the problems in the society. Thus explains how he approached the Israeli-Palestinian conflict with the religious dimension as the basis. When he conducted the interfaith dialogue on Israeli-Palestinian, he emphasized to share the same history of Israeli-Palestinian conflict and Abrahamic tradition (religion) rather than to explore the debate over the authority of the land. In the conflict Israeli-Palestinian, the exclusive religious perspective exists in both sides. The Islamic side argued that Jews has the right to live on the Holy land, but their rights as the minority under Islamic law. They dream that Muslims will rule Palestine again and become a dominant majority in the future. Meanwhile, the Jews side has argued that their exclusive religious identity, ideology, and theology has manifested itself in politics as well as in cultural and religious practices by the settlers in West Bank and Gaza Strip (Nimer 2004:496).

The identity as Muslims in Palestine is often re-framed by Hamas and other Jihadis movement to construct the meaning of Jihad. These groups are often classified by scholars as the groups that support the violence approach in Islamic tradition. They portray the religious dimension on the Islamic source, al-Qur'an and Hadits, to support the uses of violence in dealing with conflicts. It is a religious duty for Muslims to support

DINIKA, Volume 3, Number I, January - April 2018 
their religion if it is under oppression, thus entail the duty to fight with others. The scholars of these groups neglected the term of non-violence approach in dealing with conflicts and the idea of non-violence is against Islamic tradition (Nimer 2010:42).

In his book, "Non-violence and peace-building in Islam; Theory and Practice", Mohammed Abu-Nimer tries to counter the negative stigmatization toward interfaith dialogues. Using the Islamic source (Qur'an and Hadits), he explores the role of religion in peace-building activity. Moreover, when dealing with conflicts, it is important to see the culture of society. Mohammed Abu-Nimer said that Muslim community in Indonesia may differ in dealing with conflicts compared to the Sunni Muslims in Lebanon. This is how we deal with conflicts by recognizing and combining the custom and culture of the society (Nimer 2010:5). For instance, the conflict among group leaders in placing Hajar Aswad during the rebuilding of Ka'bah, Prophet Muhammad solved it not only by claiming the religious dimension but also by recognizing the culture of the leaders at that period. To accommodate these leaders, Prophet Muhammad then gave each leader a chance to place Hajar Aswad together. He asked them to bring a robe and put it on the ground. Then, he put Hajar Aswad in the middle of the robe and asked the leaders of each clan to hold the rim of the robe and lift it together (Anand, 2015: 67). From this story, the role of mediator is very important. Not only should they be aware and understand of religious teaching but also the culture of each participants. Another instance of religious dimension is when Mohammed Abu Nimer proposed to counter extremists by describing the verse on Sabr (patience):

"And seek assistance (from Allah) through patience and prayer (the requirement prayer). And truly it is extremely heavy and hard except for the owner of 'Hushu' (the humble ones)" (alBaqarah [2]: 45). 
At least, there are other 15 verses on Sabr in the al-Qur'an (Nimer, 2010: 138). It indicates that Islamic teaching proposes patience for Muslim to overcome their problems rather than with violence. Patience is hard to do since it is a moral value in implementing peace building. One has to be humble to face the problems of life, discrimination and suppression, but on the other hand, one needs to ask God for help. Therefore, Islam teaches non-violence approach in dealing with problems, such as with the patience $(s a b r)$. Other verses proposes discussion or dialogue (shura) in solving problems. The participant of shura is not limited to Muslim society, but require all elements of the society (Muslim, Jews, Christian, and other). The principle of Shura (discussion or dialogue) fits and is suitable to solve inter-religious conflicts. Mohammed Abu-Nimer tried to apply this religious dimension in the process of interfaith dialogue to get broad attention and participation while it is often neglected in the process of interfaith dialogue.

In conducting the interfaith dialogue, Mohammed Abu-Nimer is aware that there are no single formula and it is related to the context and situation. But, he divides the dialogue into four phase: First, starting from the expressions of participants. In this phase, the first step to do is to get explanation and expression of the participants of interfaith dialogue. Each of participants should share their reason to participate in the dialogue and their background story. Second, learning differences of others. At this phase, participant should learn from others. What makes them different? It is important to learn how they see something and tolerate it as the nature of diversity. Third, understanding the values of others' religions. To this phase, the participants should understand the value of others after the explanation. Recognizing others is important to build equal an mutual relation in the interfaith dialogue. Fourth, new awareness of understanding other religions or groups. The last phase shows the shifting view toward other religions. After the dialogue, the participants are expected to have new awareness towards others who are different with them (Nimer 2002).

DINIKA, Volume 3, Number I, January - April 2018 


\section{Abu Nimer's Idea on Non-violence and Peace-Building}

The idea of Islam which is a religion spread through sword and violence is neglected. Many scholars emphasize on the verse of Qur'an which is reflecting the duty of jihad for Muslim to defend their religion. Jihad by some interpreters is defined as a duty in relation with holy war and that is why Islam by some observers seen as religion of war. Moreover, in the history of Islam, there were several holy wars in the name of religion ended with the glory and victory of Muslim army. According to orientalist scholars, it is interesting to portray Islam as a religion of sword and violence. They describe Islam as being powerful enough as the only option for non-Muslims under its control would be whether to accept Islam at best or reject it with facing death at worst (al-Olaqi, and Sharif 2016:45).

But, Mohammed Abu-Nimer as a scholar of peace-building and conflict resolution puts another focus on Islamic teaching of nonviolence and peace-building in Islamic tradition (Smedjeback 2004:22). Jihad in his sense is understood in broad understanding and not merely as an act of war in the battlefield to defeat the enemy, but it is understood as a struggle for each Muslim to become a better Muslim (Smedjeback 2004:22). Although Islam permits its followers to use violence as a part of self-defense, it does not mean that it is the only way. Islam has another way to solve conflicts which emphasizes on non-violence act. The scholars who are lenient to Islam who studied the connection between Islam and non-violence are Mohammed Abu Nimer, Chaiwat Satha Anand, etc. There are two contradicting situations when Muslims face a conflict or war. Nowadays, when modern technology of weapons has been invented and it can differentiate between civilians and soldiers, Muslims should not use it as justification to violence although as a way to defense themselves. However, Muslims should also be active in responding to injustices that they face. Therefore, Muslims should use non-violence act as a response and resist to injustices as Mohammed Abu-Nimer, Chaiwat Shata Anand, 
and others Islamic scholars initiate. It is because Islam has provided another way to encounter violence with non-violent act through dialogue and peace-building activities. It is better to keep one's life rather than to commit murder although that person deserves to be killed. That idea reflected in one verse in the Qur'an as follows:

“...that if anyone killed a person not in retaliation of murder, or (and) to spread mischief in the land - it would be as if he killed all mankind, and if anyone saved a life, it would be as if he saved the life of all mankind." (al-Maidah [5]: 32).

The study on Islam has to recognize the story of non-violence teaching which is often neglected by Islamic preacher and scholars. This field of non-violence in Islamic teaching should be widespread among Muslims and to other believers as a way to introduce Islam as rahmah lil alamin (mercy of the world). As a religion of mercy (rahmab), Islam contributes to create peaceful society and environment not only for Muslims but also for the entire human beings in this world. It requires Muslim consciousness to implement Islamic teaching on non-violent act to establish a peaceful world. The Islamic teaching of non-violence should be noticed and preached by Muslim preachers in order to evoke Muslims and non-Muslims that Islam is a religion of peace, not a religion of violence. Yes, Muslim could use violence in order to seek justice and defense but non-violent acts should be used to overcome injustices. Therefore, Mohammed Abu Nimer as one of Islamic scholars of nonviolence and peace-building clearly states that every religion can foster both violent and non-violent acts. The responsibility rests upon religions followers to choose non-violent acts rather than the violent ones to solve problems and cultivate the teaching of non-violent perspective from the scripture. According to Chaiwat Satha Anand, to be a real Muslim, there is no other choice except practicing and acting of non-violent acts (Anand, 2015: 32).

DINIKA, Volume 3, Number I, January - April 2018 


\section{Critics on Interfaith Dialogue and Peace-Building}

Since the end of cold war, many studies argued that the clashes of civilization were caused by race, ethnicity and religious identity. Therefore, many scholars emphasized their studies on the role of religion in the destructive conflicts. Meanwhile, the focus of the works of Mohammed Abu-Nimer is recently shifting towards religion as the source of peacebuilding. It is important since the interreligious peace-building collaborate individuals and collective identities from various religions (Nimer 2001:685).

The flaw of interfaith dialogue is the number of participants. Since the requirement of equal dialogue refer to the equal number of participants from each side, it will limit the scope of the dialogue. Therefore, dialogue are often attended only by the elites in the society and set aside commoners. This situation was clearly displayed in the interfaith dialogue in peace-building among Muslims-Christians in Ambon. Qurtuby (2013) describes them in Tim 20 Wayame and Provokator Perdamaian. The peace team of Wayame, called the Tim 20 Wayame was a voluntary team of an interfaith association which consisted of 20 people $(10$ Muslims and 10 Christians) in the village of Wayame on the shoreline of Ambon Bay (Al-Qurtuby 2013:6). The number of the members of this team is limited to the interfaith leaders, so each side had to choose their representatives to be the members of this team. These groups protected each other from violence and esthablised rules to be obeyed by Wayame people. Whoever broke this rule will get moral sanctions and physical punishement (AlQurtuby 2013:7). If we look at Nimer's opinion on interfaith dialogue, Tim 20 Wayame emphasized culture to build the peace. The representations of Muslims and Christians in this sense are only the representatives of religious identity, but the essence of religious dimension in Tim 20 Wayame emphasized the universal humanity. So, to what extent the role of leaders in Tim 20 Wayame explains their religious vision of peace to their 
members of society? This is important to understand and accept tolerance among different religions in order to keep peace.

Meanwhile Provokator Perdamaian symbolizes the recent examples of interreligious relation among Muslims and Christians in Ambon. This grassroots movement was based on the community activities to prevent and keep the peace. The founder of this movement declared that the purpose of their movement is to build peace, reinforce amity and reduce tension and escalation of conflicts in Ambon (Al-Qurtuby 2013:9-10). The use of media to spread news and teaching of peace-building is important because during the conflict, some people use text messages and spread false information or hoax for certain reasons to escalate the tension. Furthermore, their activity does not merely take place to counter the false information through social media. They are also involved in music, dance, story telling and sport groups which build trust and bridging the gap between them. In this sense, what Mohammed Abu-Nimer dreams about the culture dimension in implementing interfaith dialogue has come true. He argues that in the process of peace building, mediators apply the value and principles of Islam and Arabic culture with genereal religious understanding (Nimer 2010:165).

Therefore, peace-building activity through interfaith dialogue as mentioned above is often criticized since it is closely related to conversion issue. Usually, news on the success of interfaith dialogues in building peace and preventing conflicts from escalating is not very well spread, but the failure of interfaith process is broadly spread. Therefore, in the era of digital media, the need to promote interfaith dialogue through social media is very important. So that the movement of interfaith dialogue and peace-building practice will attract broader members of society to be involved in such of activity. Finally, the bridge of mutual understanding and tolerance will be sustainable in the society from the grassroots up to the elites. There are some improvements in the interfaith activity with the

DINIKA, Volume 3, Number I, January - April 2018 
rise of some conferences on interfaith and the establishment of interfaith centers among Muslim society such us Alexandria Interreligious conference (2002), Annual Doha Inter-faith Conference, International Conference of Islamic Scholars (ICIS) held by NU in the era of Hasyim Muzadi, Interfaith Conference in Mecca (2008), and Dialogue Betwen East and West (iniziated by Ayatollah Khomeni from Iran) (Khamami 2014:251-252).

Another peace-building activity example was conducted by an Imam and a Pastor in Nigeria. The name of the Imam is Muhammad Ashafa and the name of the pastor is James Wuye. Both of them work together to promote non-violent and peace-building activities based on interfaith dialogues. This depicts the role of religious leaders in deescalating conflicts and reducing tension through dialogues and peace-building activities. With the involvement of religious leaders from both sides, mutual understanding can be realized, though it can be very difficult at the beginning. It requires a sincerity to forgive one another for what has happened in the past. The Imam and Pastor succeeded in shifting the understanding of their people about religious orders from the act of violence to the promotion of creating peace. The people in Nigeria are well known in their spirit of religiosity. Sometimes they could to kill someone in the name of God. But, with the new understanding on the verses of the Bible and the Qur'an about the order of God to create peace, they began to blast murderers in the name of religion (Ashafa and Wuye 2017:72).

The restriction of the participants and accusation of religious conversion faced by interfaith dialogues and peace-building activities are not an obstacle to promote non-violent acts. Successful stories as described above by Qurtuby (2013) on Tim 20 Wayame and Provokator Perdamaian, and Ashafa and Wuye (2017) on their story about the role of the Imam and Pastor in Nigeria are evidence of successful non-violent activities in dealing with conflicts. Although non-violent acts are still surrounded by a set of limitations and critiques, it does not mean that we neglect it in the process 
of conflict resolutions. Muhammad Abu-Nimer and other scholars who are proponent towards non-violent acts are optimistic that such activities will widespread and used as useful means to deal with conflicts rather than violent acts.

In one of his writings, Mohammed Abu-Nimer shared his idea on the limitations and obstacles in developing peace building using religious dimension. These limitations came from both internal and external factors surrounded the issues of religion and peace building. He proposed seven notes in the limitations and obstacles faced by religions and peace building; 1) operating on the fringes, 2) no evaluation to trace the impacts, 3) limited and weak presence in academic institutions, 4) lack of religious pluralism education for children, 5) mainstreaming gender in religious peacebuilding, 6) lack of media publication of religious peace-building, 7) the interreligious enclave syndrome (Nimer 2015:16-25). Despite the field of religion and peace-building still obstructed by a number of limitations and obstacles, it requires strong commitment and patience from supporters of non-violent and peace-building acts.

\section{From Dialogue to Training}

When a conflict occurs in a certain area, third party will try to conduct a meeting for reconciliation. Then, a dialogue between both sides in a neutral area will be held to reach an agreement. It is quite difficult for the mediator to reach the agreement from the participants if they do not share their common problems after the conflict and what will happen if the conflict will still occur in the society. Therefore, a dialogue plays an important role as a bridge to unite differences, build tolerance and understand each other.

Then, how do we maintain the relationship among different religions after the conflict? Some activists of peace-building develop the training of peace-building to share ideas of peace as the best way to keep the conflict

DINIKA, Volume 3, Number I, January - April 2018 
from escalating. Mohammed Abu-Nimer as a peace-building activist argues that the participants in interreligious peace-building can share their experiences of approaching a conflict from religious perspective and how that can help them reach their associates (Nimer 2001:686). Within the training, the participants will interact day to day with each other and it will develop their understanding toward each other. For example: the act of a Jew bringing a chair so that a Muslim could sit down was perceived as a gesture of reconciliation among Judaism and Islam (Nimer 2001:686). This also happened in the peace-building among Muslims and Christians in the case of Team 20 Wayame, Ambon. Both of them will defend their brothers from an attack. Muslim in Wayame will protect their Christian brothers from the attack of other Muslims and vice versa.

The two stories above show us the great understanding of other religions and a strong tolerance within a society. Those stories also reflect the shift and changing perceptions of others, from prejudice and narrow minded to open minded. As Mohammed Abu-Nimer (2001) describes, the goal of interreligious peace-building training is to facilitate a change of participants' views from the narrow, exclusionist, antagonistic, and prejudiced attitude to a more tolerant view and open-minded attitude (Nimer 2001:686). Seeing the beneficial training of peace-building, through his activities and thoughts, Nimer combines the theory and practice in conducting interreligious peace-building training. Although it is not an easy task, the support of others towards the importance of traning in interreligious peace-building is shown in many places especially in the conflict-affected areas. The training will reframe and change the paradigm of participants toward a conflict from their own religious understanding. Therefore, he argues that interfaith dialogue and interreligious peacebuilding will not separate Muslims, Christians, Jews, and from other religions but how they understand the religions as a source of peacebuilding and not to legitimate the violent actions. 
In order to create interreligious training, Mohammed Abu-Nimer mentions three factors that must be considered in a training: First, how cognitive, affective (emotional), and behavioral factors can change the attitude of individuals in a training setting. Second, how effective it is to address participants as individuals or as a representative of their collective communities. Third, how effective experiental (Here and Now) learning is as compared to instrumental learning, which is based on new information and a knowledge or a task to be completed (Nimer 2001:686).

All of those three must be applied in designing interreligious peacebuilding training by involving religious dimension from each participant. Of course, it will impact their spirituality and change the attitudes of one towards the other. However, the important issue according to Mohammed Abu-Nimer is how to represent the role of religion in non-violent peace-building acts. As a Muslim, he examines Islam and its teaching in promoting peace-building. Meanwhile, other scholars of peace-building can also develop and examine other religions, such Christianity, Judaism, Buddhism, and so on the issues of peace-building.

Mohammed Abu-Nimer affirms that non-violent and peacebuilding concept in conflict resolution is not something new in Islamic history and teaching. His main idea is to support peace-building activities spread religious teaching (Islamic teachings) in ordering Muslims to create peace in this world. Islamic teaching of peace must be emphasized and widespread in order to counter those who are pro-violence in the name of religion. Therefore, Mohammed Abu-Nimer offers a concept to reconcile a conflict which is forgiveness, understanding, and not reply violence with violence. He did not blame violence as a way to solve conflicts because it is also an option. But, if there is another choice to deal with it in peace and non-violence, it is better to go that way and it is suggested in Islamic teaching (Rohman 2011:187).

DINIKA, Volume 3, Number I, January - April 2018 


\section{Conclusion}

The discussion above on the issues of interfaith and peace-building dialogue shows the importance of non-violent approach in building understanding and bridge the gap between the conflicting parties. The main goal of interfaith dialogue is to develop the understanding of tolerance and to shift or change prejudiced, sentimental, and narrow minded attitude to become more tolerance and open minded. The openness to accept differences starts from the understanding of religious teaching about universal humanity. Moreover, Mohammed Abu-Nimer as an activist of peace-building tries to examine the non-violent peace-building in Islamic teaching. He argues that religions nowadays are not only framed as the source to legitimate violent actions, but as the source of peace-building. The interfaith and peace-building dialogue will be more effective in the peace making sessions if the participants try to implement the dialogue to the society through the cooperation and understanding how to live in peace with others.

Although interfaith dialogue has significant benefit in creating peace, but it is often criticized as the place of religious conversion. The issue of conversion was spread out since the theme of dialogue often discussed the story of other religions. The basic assumption toward interfaith dialogue as the source of religious conversion challenges Mohammed Abu-Nimer as one of Muslim peace-building activists. His perspective toward interfaith dialogue is not merely conducting an interfaith training, but also tries to develop religious dimension in every activity of peace-building movement. Therefore, through interfaith dialogues and peace-building activities, the participants will develop their spirituality and morality according to their religions. Furthermore, their attitude toward others will change and shift to be more tolerant and open-minded. On the other hand, religious teachings, such as in Islam as explored by Mohammed Abu-Nimer provides another way to build peace through non-violent approach. 


\section{References}

Al-Olaqi, Fahd Mohammed Taleb and Sharif, Naushad Umar. 2016. "The Sword in Islamic World View." International Journal of Philosophy and Theology Vol.4, No.: 42-54.

Al-Qurtuby, Sumanto. 2013. Peace-Building in Indonesia: Christian-Muslim Alliances in Ambon Island. Routledge: Islam and Christian-Muslim Relation.

Ashafa, Muhammad and Wuye, James. 2017. Melatih Para Juru Damai: Agamawan Muda Di Nigeria. In Ketika Agama Bawa Damai, Bukan Perang: Belajar Dari Imam Dan Pastor. Edited by Ihsan Ali-Fauzi. Jakarta: PUSAD Paramadina.

George, Cherian. 2016. Hate Spin: The Manufacture of Religious Offense and Its Threat to Democracy. London: MIT Press.

Kaufmann, Stuart J. 2006. "Escaping the Symbolic Politics Trap: Reconciliation Initiatives and Conflict Resolution in Ethnic War." Journal of Peace Research Vol.43, No: 2, 201-218.

Khamami, Akhmad Rizqon. 2014. "Dialog Antar-Iman Sebagai Resolusi Konflik, Tawaran Mohammed Abu Nimer." Journal Al-Tabrir Vol.14, No: 249-271.

Nimer, Mohammed Abu. 2001. "Conflict Resolution, Culture, and Religion: Toward a Training Model of Interreligious PeaceBuilding." Journal of Peace Research Vol. 38, N: 685-704.

. 2002. "The Miracle of Transformation Through Interfaith Dialogue: Are You a Believer." In Interfaith Dialogue and PeaceBuilding, edited by David R. Smock, 15-32. Washington DC: United States Institute of Peace Press.

2010. Nirkekerasan Dan Bina-Damai Dalam Islam; Teori Dan Praktik. Jakarta: Yayasan Abad Demokrasi, Democracy Project.

-. 2015. "Journal of Inter-Religious Dialogue and State of Formation." Journal of Inter-Religious Dialogue and State of Formation. http://irdialogue.org/wp-content/uploads/2015/03/abu-nimerJIRS-Issue-16-03-31-15-FINAL-svh.pdf.

Nimer, Mohammed Abu. 2004. "Religion, Dialogue, and Non-Violent Actions in Palestinian-Israeli Conflict." International Journal of Politics, Culture, and Society 17, No.3: 491-511.

DINIKA, Volume 3, Number I, January - April 2018 
Rohman, M. Saifullah. 2011. "Revitalisasi Nirkekerasan Dan Bina Damai Menuju Perdamaian. Tinjauan Buku 'Nirkekerasan Dan Bina Damai Dalam Islam: Teori Dan Praktik' Karya Mohamed AbuNimer." Jurnal Masyarakat Dan Budaya 13 No. 2.

Salim, Emil. 2000. Kembali Ke Jalan Lurus; Essai-Essai 1966-99. Jakarta: Alvabet.

Shafiq, Muhammad and Nimer, Mohammed Abu. 2007. Interfaith Dialogue: A Guide for Muslims. London: The International Institute of Islamic Thought.

Smedjeback, Martin. 2004. "Review of Non-Violence and Peace Building in Islam; Theory and Practice by Mohammed Abu-Nimer.” http:/ / www.koed.hu/mozaik14/martins.pdf. . 
DINIKA, Volume 3, Number I, January - April 2018 